\title{
Effects of Google Classroom on the Academic Performance of Business Education Students in Cost Accounting in Federal Colleges of Education
}

\author{
RILWAN DARAMOLA ${ }^{1 *}$ \\ Department of Accounting Education \\ School of Secondary Education (Business) \\ Federal College of Education (T) Bichi, \\ Kano State, Nigeria \\ PROF. T. A. UMORU ${ }^{2}$ \\ Department of Business \& Entrepreneurship \\ Education, Kwara State University, Malete \\ Kwara State, Nigeria
}

\begin{abstract}
The study was carried out to investigate the effects of Google classroom on the academic performance of business education students in cost accounting in Federal Colleges of Education in North-West Nigeria. Quasi experimental design was adopted for the study. In order to achieve this, three specific objectives and three research questions were raised. Three null hypotheses were tested for the study. The population of the study was 241 students and the sample was 91. Cost Accounting performance Test (CAPT) was used as the instrument for data collection. The instrument consisted of two sections. Section A was the pre-test and section B was the post-test. The data collection procedure lasted for five weeks. The research questions one to three were answered using mean and standard deviation. Null hypotheses one to three were tested using Analysis of Covariance (ANCOVA). All the hypotheses were tested at 0.05 level of significance. Null hypotheses one were rejected, while hypotheses two and three were retained. The study found that Google classroom had positive effects on the academic performance of Business Education students in Cost accounting. However, there was no significant gender effect on the academic performance of male and female students who were taught cost accounting using Google classroom. There was a significant difference in the academic performance of business education students taught Cost Accounting using Google classroom and lecture method. Based on the findings, it was concluded that Google classroom affected the academic performance of business education students in cost accounting. It was recommended among others that Google classroom should be used to teach cost accounting to Business Education students in Colleges of Education. Keywords: Classroom, Social Media, Academic Performance, Business Education and Cost Accounting DOI: $10.7176 / \mathrm{JEP} / 12-9-03$
\end{abstract}

Publication date:March $31^{\text {st }} 2021$

\section{Introduction}

Education is one of the sources of dynamic changes in contemporary society. It accelerates development, engenders self-reliance, community interaction and national integration. Education also promotes researches which lead to technological development. It grooms its users, inculcates moral values and adds knowledge. The concept of education has undergone a major shift, in recent times, from teacher-centric to learner or learningcentric. Earlier, teachers played the role of knowledge providers, but now their role has expanded. There is a lot of emphasis on integrating technology in the classroom through innovative teaching strategies that focus on enabling students to achieve the desired learning objectives (Hwang, Lai, \& Wang, 2015). Technology facilitates increasing students' engagement (Northey, Bucic, Chylinski, \& Govind, 2015) which is critical to obtain the desired learning objectives (Bolkan, 2015).

The term 'social media' has been described by a wide range of concepts such as user-generated content, convergence culture, the audience, peer production, participating media among others (Mandibery, 2012). Each description of these new media is based on the user's perspective and the role it plays as of the time of description but, the term 'social media' has come to replace all these and become accepted by most people. Social media provide an avenue for compassion and as such are useful in highlighting social issues and triggering changes in society. Dowthwaite (2011) explained that social media allow issues to be identified, monitored and managed quickly and it also allows for real time interaction with stakeholders providing a mechanism through which disinformation can be decimated before getting out of hand. The usefulness of social media cannot be overemphasized, a careful analysis of the work of Baruah (2012) indicated that the new media have done a commendable job in bridging the communication gap between people. He further identified the role of social media to include: bridging communication gap between persons, serving as a source of information, serving as an 
important marketing tool, and preventing intrusion into privacy.

Google Classroom is a program for teachers to create a digital classroom for students to communicate with their teachers and peers (Phan, 2015). It is a free application that integrates e-mails and documents to save into storages. Teachers can upload files, videos, links, announcements and assignments for students to retrieve and view. Document files can be edited in class and shared with peers to learn collaborative skills. When students complete an assignment, they can submit by posting on the teacher's board or on the classroom board. This program can be accessed using any device at any place, which is convenient for both teachers and students. Google platform allows learners to chat and discuss topics learned in class, and allows teachers to view student discussion, and post comments. Different assignments can be posted such as video segments, PowerPoint presentations, documents and web quests.

Google classroom is considered as one of the best platforms for enhancing teachers' workflow. It provides a set of powerful features that make it an ideal tool to use with students. Google classroom helps teachers save time, keep classes organized, and improve communication with students. It is available to anyone with Google Apps for education, a free suite for productivity tools including Gmail, Drive and Docs (2015). The Google classroom application depends on Google documents and cloud storage and Gmail service in order to accomplish the required functions research and follow-up with students. On the other hand, the service also provides tools for teachers to continue to allow them to publish the assignments, homework, questionnaires and tests for students and get answers to them in real time.

Business education refers to education for business and education about business. It's a programme of study that prepares students to be self-reliant. Business education is that aspect of education that inculcates in its recipients attitudes, knowledge, skills, value that are required in the world of work and business (Salome, 2012).

Academic performance plays an important role in an individual placement either in the academic institutions or job placement. The pursuit of academic performance is a global phenomenon.

Cost accounting examines the cost structure of a business by collecting information relating to costs incurred by a company's activities assigning selected cost to products and services and other cost objects and evaluating the efficiency of cost usage.

Gender alone does not determine academic performance, it can be influenced by other factors which include environment of the learners (rural and urban); socio-economic class, study habit, teacher qualifications, experience, availability of instructional facilities and infrastructure, among others. Most of the courses are taught using the traditional method which also affect the performance of students in business education.

\section{Statement of the Problem}

Teachers have the major obligation of empowering students with specific skills, knowledge and attitude that will enable them to live and work in the knowledge society. The current traditional method of teaching cost accounting in Federal Colleges of Education in North-West, Nigeria is seems inadequate to the detriment of the academic performance of business education students. Cost accounting is a vital and major part of Business Education programme in Nigerian tertiary institutions. Unfortunately, where cost accounting is being offered as a major course, the rate of failure in the course is quite alarming. The summary of the analyses of business education students' performance in cost accounting for 2015/2016, 2016/2017 and 2017/2018 academic sessions in three Federal Colleges of Education in North-West, Nigeria: Federal College of Education Kano, Kano State, Federal College of Education, Zaria Kaduna State, Federal College of Education, Katsina, Katsina State, offering Business Education are given as follows. For 2015/2016 academic session - out of 122 students, 46 (37.7\%) passed, while $76(62.3 \%)$ failed and for 2016/2017 academic session, out of 119 students $48(40.3 \%)$ passed, while 71 students (59.7\%) failed. For 2017/2018 academic session out, of 130 students, 51 (39.2\%) passed while $79(60.8 \%)$ failed). If this poor performance goes unchecked, the competence of NCE Business Education (Accounting Option) graduates becomes questionable and they will become irrelevant in the world of work.

Based on the researcher's recent interaction with some students, it was observed that even with the incorporation of ICT into the curriculum of business education, lecturers still prefer to use the traditional method in teaching cost accounting. Also, business education students believe that cost accounting is too technical and difficult, and that is why lecturers are finding it difficult to teach effectively. On the basis of the foregoing, the researcher is prompted to investigate the effects of Google classroom on the academic performance of business education students in cost accounting in Federal Colleges of Education in North-West, Nigeria.

The situation presented here calls for great concern for both lecturers and students. Even at this, most students that passed did not pass at first sitting. There is a dire need to address this situation. This is what the study intends to do by investigating the effects of Google classroom on the academic performance of Business Education students in cost accounting in Federal College of Education in North-West, Nigeria.

\section{Purpose of the Study}

The main purpose of this study is to investigate the effects of Google classroom on the academic performance of 
Business Education students in cost accounting in Federal Colleges of Education in North-West, Nigeria. The specific purposes are to:

1. assess the effects of Google classroom on the academic performance of Business Education students in cost accounting in Federal Colleges of Education.

2. determine the effects of gender on the academic performance of Business Education students who were taught cost accounting using Google classroom in Federal Colleges of Education.

3. ascertain the interaction effect of treatment and gender on the academic performance of Business Education students taught cost accounting.

\section{Research Questions}

The study answered the following research questions:

1. What is the effect of Google classroom on the academic performance of Business Education students in cost accounting in Federal Colleges of Education?

2. What is the effect of gender on the academic performance of Business Education students who were taught cost accounting using Google classroom in Federal Colleges of Education?

3. What is the interaction effects of treatment and gender on the academic performance of Business Education students taught cost accounting?

\section{Research Hypotheses}

The following null hypotheses are formulated and were tested at 0.05 level of significance:

$\mathrm{Ho}_{1}$ : Google classroom has no significant effect on the academic performance of Business Education students in cost accounting in Federal Colleges of Education.

$\mathrm{Ho}_{2}$ : $\quad$ There is no significant difference in the academic performance of male and female Business Education students who were taught cost accounting using Google classroom in Federal Colleges of Education.

$\mathrm{Ho}_{3}$ : There is no significant interaction effects of treatment and gender on the academic performance of Business Education students taught cost accounting.

\section{Theoretical Framework}

The key theory that formed for the foundation for this study is Constructivism Learning Theory by Jean Piaget (1980)

Scholars have written extensively on constructivism as a new learning paradigm. Prominent among them in this century is Jean Piaget who posited that humans learn through construction of one logical structure after another.

This study utilises a theoretical framework based largely on social constructivism which attributes much of human being's learning to their surroundings and experiences. John Dewey, as well as Lev Vygotsky assumed that humans learning is inseparable from their experience (Liu and Chen, 2010). With this in mind technology integration and the very hand-on nature of it rest primarily on the constructivists theory in its original form (Schcolink, Kol \& Abarbanel, 2016). In other words, as students engage in the technology-centred classroom, they learn from the interactivity and experiences therein. Students learn more constructivists hold when they are able to construct the information for themselves rather than hearing and repeating it.

Knowledge, therefore, is not transferred to them via a professor or teacher, but rather through an experimental involvement in the acquisition of knowledge (Lin \& Jou, 2013). Various forms of this theory have been utilised in education with the focus of the classroom moving from teacher-centred to student-centred learning (Ougang \& Standley, 2014).

\section{Conceptual Framework}

Innovative pedagogy is a learning approach focused on the development of innovation competencies defining how knowledge is assimilated, produced and used in manner that can create innovation (Duktur, 2016). He emphasize that innovative pedagogy will enhance and improve the educational aspects of business education where the traditional approach could not deliver. The conceptual framework is shown in figure below.

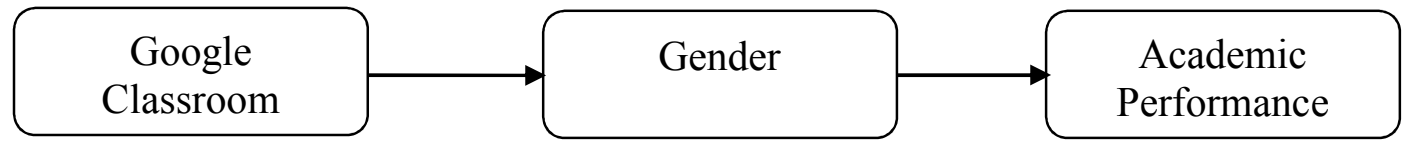

Fig. 1 Conceptual Framework (Source: The Researcher, 2020)

In this study, Google classroom is the independent variables, gender is the moderating variable while academic performance dependant variable. The independent variables in the research have a strong relationship to the dependent variable. The framework tends to guide the relationships between independent and dependent variables, with independent variables directly influence dependent variable in the research study. 


\section{Methodology}

The study employed the quasi-experimental design. Specifically, pre-test and post-test non-equivalent control group design was used. The design was considered appropriate because it was not possible for the researcher to assign subjects randomly to the groups. The population of the study was 241 students. It comprised NCEIII Business Education (Accounting Option) students who offered cost accounting in the Federal Colleges of Education in North-West, Nigeria. 74 respondents were drawn as sample size for the study. Two colleges of education was sampled, they are Federal College of Education, Zaria and Federal College of Education, Katsina using purposive sampling. The instrument for data collection was Cost Accounting Performance Test (CAPT) containing section A for pre-test and section B for Post-Test. After using this technique, Federal College of Education, Kano was assigned to E1 (Experimental Group 1, Google classroom); and Federal College of Education, Katsina was assigned to the control group (Control Group). The demographic variable was analysed using percentage while the data for the research questions 1 - 3 were analysed using mean and standard deviation. Null hypotheses one to three were tested using Analysis of Covariance (ANCOVA). All the hypotheses were tested at 0.05 level of significance. Analysis of Covariance (ANCOVA) was considered appropriate for testing variables because it is used to establish that two or three groups were equivalent before treatment groups.

Research Question One: What is the effect of Google Classroom on the Academic Performance of Business Education Students taught Cost Accounting in Federal Colleges of Education?

Data collected explained the research question as shown in Table 1

Table 1: Descriptive Statistics for Google classroom and control groups

\begin{tabular}{llll}
\hline Group & N & Mean & Std \\
\hline Experimental II (Google classroom) & 40 & 60.33 & 6.97 \\
Control Group (Lecture method) & 34 & 46.82 & 4.73 \\
\hline
\end{tabular}

Source: Field Experiment, 2020

The data in Table 1 reveals that the participants in treatment group (Google classroom) performed better than their counterparts in the control group (Lecture method) because they had the highest post-test mean score (mean $=60.33$ ) as against the post-test mean score of the control group (mean $=46.82$ ). This implies that Google classroom is effective for improving the academic performance of Business education students in cost accounting. Research Question Two: What is the effect of gender on the academic performance of Business Education students who were taught cost accounting using Google classroom in Federal Colleges of Education?

Data collected explained this research question as shown in Table 2

Table 2: Descriptive Statistics for Google Classroom and Gender group

\begin{tabular}{llll}
\hline Group & N & Mean & Std \\
\hline Male & 30 & 61.20 & 7.355 \\
Female & 10 & 57.70 & 5.122
\end{tabular}

Source: Field Experiment, 2020

The data in Table 2 shows the mean score for the two groups. The table reveals that the male participants in the treatment group (Google classroom) performed better than their female counterparts because they had the highest post-test mean score $($ mean $=61.20)$ as against the post-test mean score of the female counterparts (mean=57.70). The implies that google classroom is effective for improving the academic performance of the male business education students taught cost accounting.

Hypotheses Testing

$\mathrm{HO}_{2}$ : Google classroom has no significant effects on the academic performance of Business

Education students taught cost accounting in Federal Colleges of Education.

Table 3: Summary of Analysis of Covariance (ANCOVA) for Test of Significance of main effect treatment of Google classroom on academic performance of Business education students taught Cost Accounting

\begin{tabular}{lrrrrr}
\hline \multicolumn{1}{c}{ Source Variance } & Sum of Squares & Df & Mean Square & F & Sig. \\
\hline Corrected Model & $3352.835^{\text {a }}$ & 2 & 1676.417 & 45.204 & .000 \\
Intercept & 538.770 & 1 & 538.770 & 14.528 & .000 \\
pre-test & 2.645 & 1 & 2.645 & .071 & .790 \\
Treatment & 3292.172 & 1 & 3292.172 & 88.772 & .000 \\
Error & 2633.071 & 71 & 37.086 & & \\
Total & 222743.000 & 74 & & & \\
Corrected Total & 5985.905 & 73 & & & \\
\hline
\end{tabular}

a. $\mathrm{R}$ Squared $=.560$ (Adjusted R Squared $=.548)$

Source: Field experiment, 2020

The data presented in Table 3 shows F-calculated value for effects of treatment of Google classroom on the academic performance of business education students taught cost accounting as 88.77. The Table shows that there was significant main effect of treatment of Google classroom on the academic performance of business education 
students taught cost accounting $(\mathrm{F}=88.772 ; \mathrm{P}=.000)$. Hence, the null hypothesis that stated that Google classroom has no significant effect on the academic performance of business education students taught Cost accounting in Federal Colleges of Education in North-West Nigeria was therefore rejected. This implied that Google classroom has positive effect on the academic performance of business education students taught cost accounting. This means that the effect observed was due to the main treatment given to students.

$\mathrm{HO}_{4}$ : There is no significant difference on the academic performance of male and female Business education students who were taught cost accounting using Google classroom in Federal Colleges of Education.

Table 4: Summary of Analysis of Covariance (ANCOVA) for Test of Significance of Effects of Gender on academic performance of Business education students taught cost accounting using Google classroom

\begin{tabular}{lrrrrr}
\hline \multicolumn{1}{c}{ Source Variance } & Sum of Squares & df & Mean Square & \multicolumn{1}{c}{ F } & Sig. \\
\hline Corrected Model & $3469.216^{\mathrm{a}}$ & 4 & 867.304 & 23.779 & .000 \\
Intercept & 624.541 & 1 & 624.541 & 17.123 & .000 \\
Pre-Test & 1.705 & 1 & 1.705 & .047 & .829 \\
Groups & 2390.118 & 1 & 2390.118 & 65.530 & .000 \\
Gender & 12.905 & 1 & 12.905 & .354 & .554 \\
Groups * Gender & 108.801 & 1 & 108.801 & 2.983 & .089 \\
Error & 2516.689 & 69 & 36.474 & & \\
Total & 222743.000 & 74 & & & \\
Corrected Total & 5985.905 & 73 & & & \\
\hline
\end{tabular}

a. $\mathrm{R}$ Squared $=.580$ (Adjusted R Squared $=.555)$

Source: Field experiment, 2020

The data presented in Table 4 shows F-calculated values for effect of gender on the academic performance of business education students taught cost accounting using Google classroom as 0.35 . The Table showed that there was no significant gender effect on the academic performance of business education students taught cost accounting using Google classroom $(\mathrm{F}=0.354 ; \mathrm{p}>0.05)$. Hence, the null hypothesis that stated that there is no significant effect of gender on the academic performance of business education students taught cost accounting using Google classroom in Federal Colleges of Education in North-West Nigeria is therefore not rejected. This implies that gender has no effect on the academic performance of students in cost accounting. This means that male and female students performed alike.

Table 5: Summary of Analysis of Covariance (ANCOVA) for Test of Significance of Effects of Treatments and Gender on academic performance of Business education students taught cost accounting

\begin{tabular}{lrrrrr}
\hline \multicolumn{1}{c}{ Source Variance } & Sum of Squares & df & Mean Square & \multicolumn{1}{c}{ F } & Sig. \\
\hline Corrected Model & $3469.216^{\mathrm{a}}$ & 4 & 867.304 & 23.779 & .000 \\
Intercept & 624.541 & 1 & 624.541 & 17.123 & .000 \\
Pre-Test & 1.705 & 1 & 1.705 & .047 & .829 \\
Groups & 2390.118 & 1 & 2390.118 & 65.530 & .000 \\
Gender & 12.905 & 1 & 12.905 & .354 & .554 \\
Groups * Gender & 108.801 & 1 & 108.801 & 2.983 & .089 \\
Error & 2516.689 & 69 & 36.474 & & \\
Total & 222743.000 & 74 & & & \\
Corrected Total & 5985.905 & 73 & & &
\end{tabular}

a. $\mathrm{R}$ Squared $=.580$ (Adjusted R Squared $=.555)$

Source: Field experiment, 2020

The data presented in Table 5 shows F-calculated value for interaction effect of treatment of Google classroom and gender on academic performance of business education students taught cost accounting $(\mathrm{F}=2.983$; $\mathrm{P}=0.089$ ) which indicated no significant interaction effect of treatment of Google classroom and gender on the academic performance of business education students taught cost accounting. Hence, the null hypothesis is therefore not rejected.

\section{Discussion of the findings}

The study found that Google classroom had positive effects on the academic performance of students in cost accounting. This implies that Google classroom is better in improving students' academic performance than the lecture method. This result is in line with the findings of Anupam (2014), who reported that Google classroom is very effective in the attainment of skills by the learners at their own pace and that it increases academic performance and independent learning. This finding also agrees with that of Emaikwu (2012) who reported that students who were taught using Google classroom performed better than those taught using lecture method.

The study found there was no significant gender effect on the academic performance of Business education students taught cost accounting using Google classroom. This implied that gender had no effect on the academic 
performance of business education students taught cost accounting using Google classroom. This means that male and female students performed alike. This result indicated that the effectiveness of using Google classroom as an instructional aid does not depend on gender (male and female). This revealed that Google classroom is more effective than lecture method at improving students' performance in cost accounting, regardless of gender. This is in line with the findings of Damia (2014) who found that students' performance is not determined by gender in terms of interaction and treatments on students' academic performance. The findings also agree with Simiku and Patricia (2016) who conducted a research on the effects of dialogic method of teaching on students' achievement in marketing in Colleges of Education in Delta State. The researcher studied 106 NCE II business education students where they compared lecture method with dialogic method and found that there was no difference in the mean achievement scores of male and female students in the Marketing Achievement Test (MAT) as a result of the treatment given to them. The findings of the study had significant positive effects on the mean achievement scores of both male and female NCE II business education students.

\section{Conclusion}

Based on the findings of the study, it was concluded that Goggle classroom had positive effects on business education students' academic performance in cost accounting. This implies that the lecture method which is the popular method of teaching used by business education lecturers in teaching cost accounting is not as effective as the use of Goggle classroom.

\section{Recommendations}

Based on the findings of the study, the following recommendations are made:

1. Google classroom should be frequently used by lecturers to teach business education students cost accounting in colleges of education.

2. That male and female business education students in colleges of education should be taught cost accounting by lecturers using Classroom. This is because of its numerous benefits to both genders.

3. Business education lecturers should endeavour to acquire ICT skills in order to meet the modern method of teaching

4. The National Commission of colleges of education should call for the review of course curriculum to be in line with current method of teaching.

\section{References}

Baruah, T. D. (2012). Effectiveness of Social Media as a Tool of Communication and its Potential for Technology Enabled Connections: A Micro-Level Study. International Journal of Scientific and Research Publications. 2(5), 1-11.

Bolkan, S. (2015). Intellectually stimulating students' intrinsic motivation: The Medicating influence of Affective Learning and Student Engagement. Communication Reports 28(2), 80-91. https://doiorg/10.1080/08934215.2014.962752

Damia Peter. O. (2014). Effects of Gender on Students' Academic Achievement in Secondary School Social Studies. Journal of Education and Practice. http://www.isiteorg(online) Vol. 5, No.21.

Dowthwaite, K. A. (2011). A Theoretical and Empirical Study of Social Media as a Crisis Communication Channel in the Aftermath of the BP Gulf of Mexico Oil Spill (Master Thesis) Copenhagen Business School, 24-29.

Duktur, S. L. (2016). Innovative approaches to the teaching of financial accounting in senior secondary schools in Plateau State. Nigerian Journal of Business Education 3(2), 151-157.

Emaikwu S. O (2012). Assessing the Relative Effectiveness of Three Teaching Methods in the Measurement of Students' Achievement in Mathematics. Journal of Emerging trends in Educational Research and Policy Studies, 3(4), 479-486

Hwang, G., J. Lai, C. L. \& Wang, S. Y. (2015). Seamless flipped learning: A mobile technology enhanced flipped classroom with effective learning strategies. Journal of Computers in Education, 2(4), 449-473, https:doi.org/10.1007/540692-015-0043-0

Liu, C. C. \& Chen, I. J. (2010). Evaluation of Constructivism. Contemporary Issues in Education Research, 3(4), 63-66.

Mandiberg, M. (2012). Introduction in the Social Media Reader, edited by Michael Mandiberg, New York: New York University Press, 1-10.

Northey, G., Bucic, T. Chylinski, M. \& Govind, R. (2015). Increasing student engagement using Asynchronous Learning, Journal of Marketing Education, 37(3) 171-180. https://doi.org/10.1177/0273475315589814

Ougang, J. R. \& Standley, N. (2014). Theories and research in Educational technology and Distance learning instruction through blackboard. Universal Journal of Education Research, 2(2), 161-171. Doil013189 ufer 2014.020208

Phan, W. (2015). Head Back to School with New Features in Google Classroom. Google for Education. Available: 
http://googleforeducation.blogspot.com/2015/08/headback-to-school-with-new-features-in-GoogleClassroom.html

Salome, E. N. (2012). The teacher and skills acquisition at Business Education: From the perspective of Accounting Skills. Arabian Journal of Business and Management Review, 2(4) 1-15.

Schcolnik, M., Kol. S., \& Abarbanel, J. (2016). Constructivism in Theory and Practices. English Teaching Forum. 4, 12-20.

Simuku, H. W. \& Patricia, O. (2016) Effects of Dialogic Method of Teaching Student's Achievement in Marketing in Colleges of Education in Delta State Nigeria. Nigerian Journal of Business Education. 3(1). 